\title{
Retinopathy and subconjunctival haemorrhage in patients with chronic viral hepatitis receiving interferon alfa
}

\author{
Seiji Hayasaka, Masamitsu Fujii, Yukari Yamamoto, Sachiko Noda, Hiroko Kurome, \\ Michiru Sasaki
}

\begin{abstract}
A total of 43 patients (86 eyes) with chronic viral hepatitis were examined prospectively before and after the start of interferon therapy. Of 37 non-diabetic patients, 23 (group A1) did not have retinopathy or subconjunctival haemorrhage, 11 (group A2) developed retinopathy, and three (group A3) exhibited subconjunctival haemorrhage during the treatment. In most eyes, the retinopathy disappeared after therapy was stopped. Of six diabetic patients, three (group B1) developed retinopathy and three (group B2) showed progression of existing retinopathy. Thrombocytopenia was not associated with the retinopathy in any patient. The patients' good visual acuity remained unchanged, even after retinal changes appeared. Ophthalmologists should be aware that retinopathy and subconjunctival haemorrhage may develop in patients with chronic viral hepatitis receiving interferon therapy.

(Brf Ophthalmol 1995; 79: 150-152)
\end{abstract}

Interferon alfa has been used to treat several disorders including renal cell carcinoma, macular degeneration, and chronic viral hepatitis. $^{1-6}$ Guyer and associates ${ }^{2}$ have reported on retinal ischaemia associated with the use of interferon alfa in the treatment of various illnesses. Isaka and co-workers, ${ }^{3}$ Imaizumi and associates, ${ }^{5}$ and Futami et $a l^{6}$

Accepted for publication 20 October 1994

Table 1 Clinical findings of 43 patients with chronic hepatitis receiving interferon therapy

\begin{tabular}{|c|c|c|c|c|c|}
\hline & \multicolumn{5}{|l|}{ Groups } \\
\hline & $\begin{array}{l}A 1 \\
(n=23)\end{array}$ & $\begin{array}{l}A 2 \\
(n=11)\end{array}$ & $\begin{array}{l}A 3 \\
(n=3)\end{array}$ & $\begin{array}{l}B 1 \\
(n=3)\end{array}$ & $\begin{array}{l}B 2 \\
(n=3)\end{array}$ \\
\hline $\begin{array}{l}\text { Sex (M:F) } \\
\text { Age (years) }\end{array}$ & $11: 12$ & $5: 6$ & $2: 1$ & $3: 0$ & $1: 2$ \\
\hline $\begin{array}{l}\text { Mean } \\
\text { Range }\end{array}$ & $\begin{array}{l}58 \cdot 6 \\
40-71\end{array}$ & $\begin{array}{l}61 \cdot 5 \\
41-72\end{array}$ & $\begin{array}{l}46 \cdot 5 \\
42-51\end{array}$ & $\begin{array}{l}53 \cdot 0 \\
45-61\end{array}$ & $\begin{array}{l}58 \cdot 5 \\
46-65\end{array}$ \\
\hline Chronic hepatitis & & & & & \\
\hline $\begin{array}{l}\text { C } \\
\text { B }\end{array}$ & $\begin{array}{r}21 \\
2\end{array}$ & $\begin{array}{r}11 \\
0\end{array}$ & $\begin{array}{l}2 \\
1\end{array}$ & $\begin{array}{l}3 \\
0\end{array}$ & $\begin{array}{l}2 \\
1\end{array}$ \\
\hline Duration of liver dysfunction (years) & & & & & \\
\hline $\begin{array}{l}\text { Mean } \\
\text { Range }\end{array}$ & $\begin{array}{l}2 \cdot 2 \\
0 \cdot 5-7\end{array}$ & $\begin{array}{l}2 \cdot 1 \\
0 \cdot 5-6\end{array}$ & $\begin{array}{l}1 \\
0.5-1.5\end{array}$ & $\begin{array}{l}7 \\
0 \cdot 5-20\end{array}$ & $\begin{array}{l}2 \cdot 7 \\
0 \cdot 5-7\end{array}$ \\
\hline $\begin{array}{l}\text { Interferon therapy } \\
\text { Drug }\end{array}$ & & & & & \\
\hline $\begin{array}{l}\text { Alfa-2a } \\
\text { Alfa-2b }\end{array}$ & $\begin{array}{r}2 \\
21\end{array}$ & $\begin{array}{r}0 \\
11\end{array}$ & $\begin{array}{l}1 \\
2\end{array}$ & $\begin{array}{l}0 \\
3\end{array}$ & $\begin{array}{l}1 \\
2\end{array}$ \\
\hline $\begin{array}{l}\text { Initial dose } \\
\quad 6 \times 10^{6} \mathrm{U} / \text { day, } 6 \text { times per week } \\
10 \times 10^{6} \mathrm{U} / \text { day, } 6 \text { times per week } \\
\text { Duration (weeks) }\end{array}$ & $\begin{array}{r}14 \\
9\end{array}$ & $\begin{array}{l}2 \\
9\end{array}$ & $\begin{array}{l}1 \\
2\end{array}$ & $\begin{array}{l}0 \\
3\end{array}$ & $\begin{array}{l}0 \\
3\end{array}$ \\
\hline $\begin{array}{l}6-12 \\
13-24\end{array}$ & $\begin{array}{r}18 \\
5\end{array}$ & $\begin{array}{l}4 \\
7\end{array}$ & $\begin{array}{l}1 \\
2\end{array}$ & $\begin{array}{l}2 \\
1\end{array}$ & $\begin{array}{l}2 \\
1\end{array}$ \\
\hline
\end{tabular}

have described retinopathy in patients receiving interferon. To our knowledge, however, a prospective study of ocular conditions in patients with chronic hepatitis before and after interferon therapy may be rare. In the present study, we examined prospectively the eyes of patients with chronic viral hepatitis who were receiving interferon alfa.

\section{Subjects and methods}

We examined 43 patients (86 eyes) with chronic viral hepatitis who received interferon alfa at Shimane Medical University Hospital and affiliated hospitals in early 1993. Their diagnoses were based on clinical findings, liver dysfunction, and positive antibody titres to hepatitis B or C virus or to hepatitis B or C virus RNA. The patients' eyes were examined prospectively 1 month before the onset of interferon alfa therapy and biweekly after its start. All patients had an ophthalmic evaluation that included visual acuity, intraocular pressure measurement, slit-lamp biomicroscopy, and fundus ophthalmoscopy. Fluorescein angiography was performed in patients with fundus abnormalities. Interferon alfa, produced by genetic recombination, was administered intramuscularly by the staff of the Department of Internal Medicine. The dosage was based on the report by Hino et al. ${ }^{1}$ Patients were divided into two groups according to the presence or absence of diabetes mellitus: group $A$ included 37 patients without diabetes, and group B constituted six patients with diabetes. According to their fundus condition before interferon therapy, patients in group B were further divided into group B1, which included three patients without retinopathy, and group B2, which contained three patients who had retinal microaneurysms. All patients were followed up ophthalmically for more than 8 months after interferon alfa therapy began.

Excluded from the present study were patients who had hypertension, severe arteriosclerosis, or collagen disease before the start of therapy and those with previous ocular trauma or surgery.

We used Student's $t$ test for statistical evaluation. Results were assumed to be significant if $\mathrm{p}<0.05$.

\section{Results}

The 37 non-diabetic patients in group A were subdivided into three smaller groups, 
Table 2 Laboratory data of 43 patients with chronic hepatitis receiving interferon therapy

\begin{tabular}{lccccc}
\hline & Groups & & & & \\
\cline { 2 - 6 } & $\begin{array}{c}A 1^{\star} \\
(n=23)\end{array}$ & $\begin{array}{c}A 2 \dagger \\
(n=11)\end{array}$ & $\begin{array}{c}A 3 \dagger \\
(n=3)\end{array}$ & $\begin{array}{c}B 1 \dagger \\
(n=3)\end{array}$ & $\begin{array}{c}B 2^{\star} \\
(n=3)\end{array}$ \\
\hline RBC $\left(10^{10} /\right)$ & 470 & 456 & 450 & 470 & 461 \\
WBC $\left(10^{9} / 1\right)$ & 425 & $411 \dagger$ & $401 \dagger$ & $426 \dagger$ & $412 \dagger$ \\
& $5 \cdot 2$ & $4 \cdot 8$ & $4 \cdot 9$ & $5 \cdot 0$ & $5 \cdot 1$ \\
Haemoglobin (g/100 ml) & $3 \cdot 2$ & $2 \cdot 9 \dagger$ & $3 \cdot 0 \dagger$ & $3 \cdot 1 \dagger$ & $3 \cdot 2 \dagger$ \\
Platelets (1010/1) & $15 \cdot 2$ & $14 \cdot 3$ & $15 \cdot 2$ & $15 \cdot 0$ & $14 \cdot 8$ \\
SGOT (IU/l) & $13 \cdot 2$ & $12 \cdot 9 \dagger$ & $14 \cdot 5 \dagger$ & $14 \cdot 3 \dagger$ & $13 \cdot 8 \dagger$ \\
& $14 \cdot 6$ & $13 \cdot 8$ & $14 \cdot 1$ & $14 \cdot 1$ & $14 \cdot 5$ \\
SGPT (IU/l) & $11 \cdot 8$ & $10 \cdot 7 \dagger$ & $11 \cdot 1 \dagger$ & $10 \cdot 8 \dagger$ & $11 \cdot 2 \dagger$ \\
& 68 & 72 & 69 & 54 & 61 \\
FPG (g/100 ml) & 52 & $70 \dagger$ & $59 \dagger$ & $40 \dagger$ & $41 \dagger$ \\
HbA C (\%) & 75 & 110 & 101 & 41 & 59 \\
Systolic blood pressure & 68 & $70 \dagger$ & $71 \dagger$ & $42 \dagger$ & $43 \dagger$ \\
(mm Hg) & 102 & 105 & 102 & 142 & 148 \\
& 106 & $101 \dagger$ & $104 \dagger$ & $154 \dagger$ & $150 \dagger$ \\
\hline
\end{tabular}

The top value is mean obtained 1 month before start of drug therapy.

The bottom value is mean recorded $\star 2.5$ months after start of the therapy or fwhen the The bottom value is mean recorded $\star 2 \cdot 5$ months after start

retinopathy or subconjunctival haemorrhage was noted.

$\mathrm{RBC}=$ red blood cell counts; $\mathrm{WBC}=$ white blood cell counts; $\mathrm{SGOT}=$ serum glutamic
oxaloacetic transaminase; $\mathrm{SGPT}=$ serum glutamic pyruvate transaminase; $\mathrm{FPG}=$ fasting plasma glucose; $\mathrm{HbA}_{1} \mathrm{C}=$ haemoglobin $\mathrm{A}_{1} \mathrm{C}$.

$t p>0.05$ when compared with the value of group $A 1$.

according to development of retinopathy or subconjunctival haemorrhage after the start of interferon therapy. In group $\mathrm{A} 1,23$ patients had no retinopathy or subconjunctival haemorrhage; in group A2, 11 patients had retinopathy; and in group A3, three patients had subconjunctival haemorrhage.

Clinical findings in the five groups are shown in Table 1. A total of 43 patients (22 men and 21 women) were treated with interferon. They ranged in age from 40 to 72 years. Of these patients, 39 had chronic hepatitis C and four had chronic hepatitis B. Duration of liver dysfunction ranged from 0.5 to 20 years. Four patients received interferon alfa-2a, and 39 patients received interferon alfa- $2 b$. Several doses of interferon alfa were given for different durations.

Laboratory data of 43 patients are shown in Table 2. White blood cell counts were less after interferon administration than before therapy in each group. Red blood cell counts, white blood cell counts, haemoglobin levels, platelet counts, serum glutamic oxaloacetic transaminase, serum glutamic pyruvate transaminase, fasting plasma glucose levels, and systolic blood pressures after the start of the interferon therapy were not significantly $(p>0.05)$ different among the five groups. Ophthalmic findings of 33 patients are shown in Table 3. The good visual acuities (better than $0 \cdot 7$ ) remained unchanged in all patients during therapy. Retinopathy developed in 22 eyes of group A2 at a mean duration of 10 weeks after the start of therapy. Of 22 eyes, two had microaneurysms, 16 had cotton wool spots, two had microaneurysms and cotton wool spots, and two had cotton wool spots, microaneurysms, and haemorrhages. The retinopathy in group A2 remained almost stable during therapy. Subconjunctival haemorrhage developed at a mean duration of 6 weeks after the start of therapy in three eyes of group A3. Subconjunctival haemorrhage in group A3 patients disappeared 1-2 weeks later. Retinopathy developed in six eyes of group B1 at a mean duration of 8 weeks after start of therapy. Of six eyes, two had microaneurysms, two had cotton wool spots, and two had cotton wool spots, microaneurysms, and haemorrhages. The retinopathy in group B1 remained stable during therapy. Of six eyes of group B2, which had only microaneurysms before interferon therapy, four developed cotton wool spots after treatment, and two developed cotton wool spots and haemorrhages. Retinopathies in 18 eyes of group A2 and in two eyes of group B1 resolved after the interferon therapy was discontinued.

\section{Discussion}

Isaka and co-workers ${ }^{3}$ have suggested that thrombocytopenia may be involved in the pathogenesis of interferon associated retinopathy. In our present study, however, we found no significant difference in platelet counts between groups $\mathrm{A} 1$ and $\mathrm{A} 2$ or between groups A1 and B1. It is unlikely that the red blood cell counts, haemoglobin levels, glutamic oxaloacetic transaminase levels, glutamate pyruvate transaminase levels, and blood pressures were related to the development of retinopathy in our patients. It is likely that the high dose and long duration of interferon therapy may have been associated with the development of retinopathy. However, the exact mechanism of retinopathy in patients

Table 3 Ophthalmic findings of 43 patients with chronic hepatitis receiving interferon therapy

\begin{tabular}{|c|c|c|c|c|c|}
\hline & \multicolumn{5}{|l|}{ Group } \\
\hline & $\begin{array}{l}A 1 \\
(n=46 \text { eyes })\end{array}$ & $\begin{array}{l}A 2 \\
(n=22 \text { eyes })\end{array}$ & $\begin{array}{l}A 3 \\
(n=6 \text { eyes })\end{array}$ & $\begin{array}{l}B 1 \\
(n=6 \text { eyes })\end{array}$ & $\begin{array}{l}B 2 \\
(n=6 \text { eyes })\end{array}$ \\
\hline \multicolumn{6}{|l|}{ Visual acuity } \\
\hline$\geqslant 1 \cdot 0$ & 31 & 15 & 6 & 2 & 3 \\
\hline $0.7-0.9$ & 15 & 7 & 0 & 4 & 3 \\
\hline \multicolumn{6}{|l|}{ Appearance after start of interferon therapy (mean duration) } \\
\hline Of subconjunctival haemorrhage & 0 & 0 & 3 (6 weeks) & 0 & 0 \\
\hline Of retinopathy & 0 & 22 (10 weeks) & 0 & 6 (8 weeks) & \\
\hline \multicolumn{6}{|l|}{ Retinal findings } \\
\hline Microaneurysms & & $\begin{array}{r}2 \\
16\end{array}$ & & 2 & \\
\hline $\begin{array}{l}\text { Cotton wool spot } \\
\text { Cotton wool spot plus microaneurysms }\end{array}$ & & $\begin{array}{r}16 \\
2\end{array}$ & & 2 & 4 \\
\hline Cotton wool spot, microaneurysms, plus haemorrhage & & 2 & & 2 & 2 \\
\hline \multicolumn{6}{|l|}{$\begin{array}{l}\text { Disappearance of subconjunctival haemorrhage } \\
\text { (mean duration) }\end{array}$} \\
\hline \multicolumn{6}{|l|}{ Changes in retinopathy after interferon endst } \\
\hline Disappearance & & 18 & & 2 & \\
\hline Continue & & 4 & & 4 & 6 \\
\hline
\end{tabular}

*The worst value during the interferon therapy.

tRetinal findings 2 months after interferon therapy is stopped. 
with chronic viral hepatitis receiving interferon therapy is unclear.

Subconjunctival haemorrhage reportedly develops in patients with minor local trauma, systemic hypertension, and acute conjunctivitis. ${ }^{7}$ Our patients in group A3 had no such disorders. It is possible that the subconjunctival haemorrhages seen in group A3 patients may have been related to the interferon therapy.

Guyer and associates ${ }^{2}$ have reported that retinal complications may be reversible when treatment is stopped. In most of our nondiabetic patients in group A2, the retinopathy disappeared after the interferon was stopped. In most of our diabetic patients in group B1 and B2, however, the retinopathy continued.

Our findings showed that the patients' good visual acuities remained unchanged, even when retinopathy occurred. Guyer and co-workers ${ }^{2}$ described a case of visual loss associated with interferon therapy. Ophthalmologists should be aware that retinopathy and subconjunctival haemorrhage may develop in patients with chronic viral hepatitis receiving interferon therapy.

The authors thank Dr T Setogawa and the staff of the Department of Internal Medicine for advice, Ms MA Gere fo editorial assistance, and Miss $Y$ Yasuda for secretarial assistance.

1 Hino K, Suzuki H, Yamamoto Y, Iino S, Ogawa N. A comparative study of interferon $\alpha-2 b$ for the treatment of chronic hepatitis C. Kiso-to-Rinsho (Clin Report) 1992; 26: 409-42.

2 Guyer DR, Tiedeman J, Yannuzzi LA, Slakter IS, Parke D, Kelley J, et al. Interferon-associated retinopathy. Arch Kelley J, et al. Interferon-asso

3 Isaka Y, Nishi Y, Ito Y, Seki K. Ophthalmic manifestations of interferon therapy in eight patients. Folia Ophthalmol fpn 1993; 44: 1054-8.

4 Poliner LS, Tornambe PE, Michelson PE, Heitzmann JG. Interferon alfa-2b for subfoveal neovascularization in agerelated macular degeneration. Ophthalmology 1993; 100: 1417-24.

5 Imaizumi $\mathrm{H}$, Takeda $\mathrm{M}$, Okushiba $\mathrm{U}$, Abe $\mathrm{N}$, Tamiya $\mathrm{M}$ Nakahira Y, et al. Retinal vascular lesions in patients under systemic interferon therapy. Rinsho Ganka 1994; 48: 171-5.

6 Futami H, Chuuma T, Naoi N, Sawada A, Shingehira M Tubouchi $\mathrm{H}$. Ocular complications during systemic interfubouchi $H$. Ocular complications during system therapy. Rinsho Ganka 1994; 48: 533-7.

7 Fukuyama J, Hayasaka S, Yamada K, Setogawa T. Causes o subconjunctival hemorrhage. Ophthalmologica 1990; 200 63-7. 